\title{
Progesterone Receptor Positive by Immunohistochemistry 31-40 Percent
}

National Cancer Institute

\section{Source}

National Cancer Institute. Progesterone Receptor Positive by Immunohistochemistry 31 -

40 Percent. NCI Thesaurus. Code C141451.

An immunohistochemical staining finding indicating that 31-40 percent of the cells in a tissue sample are expressing progesterone receptor. 